\title{
Sources of Inspiration of Nordic Procedural Law: Choices and Objectives of the Legal Reforms
}

\author{
Maria Astrup Hjort
}

\begin{abstract}
This article is based on the following question: does Nordic procedural law exist? Procedural law is often regarded as a national matter, and, unlike in many other legal disciplines, there has not been any official Nordic legislative collaboration in this field. Whether one can refer to procedural law as Nordic or not also has an impact on our perception of procedural law as part of a Nordic community. One way of examining the 'Nordic-ness' of procedural law is to examine the sources of inspiration used when reforming procedural codes and acts. These sources are found in the preparatory works to the legislation. This article surveys the sources that have been used to reform the procedural codes and acts in the Nordic countries over the last three centuries and shows how the objects for the procedural reforms have an impact on the choice of sources of inspiration. The survey also shows that the object for the reforms changes over time, and this influences the choice of sources of inspiration. Further, the use of the sources found in the preparatory works is discussed, and this brings us back to the starting point-namely whether, based on the use of the sources of inspiration, the procedural law in the Nordic countries can be described as Nordic.
\end{abstract}

\section{Introduction}

Is there such a thing as Nordic procedural law? Procedural law is traditionally recognised as a national matter, and one might argue that similarities in different countries' procedural law have either a historical explanation or are due to the fact that another country's procedural law has been used as a source of inspiration for reforming this country's procedural law. A method to survey the 'Nordic-ness' of the Nordic countries' procedural law is to examine what sources the countries have used when reforming their procedural law. In the Nordic countries, the preparatory works are an important legal source, and, in addition to being a factor in interpretation of the legislation, the preparatory works usually also contain statements on sources of inspiration for changes in the legislation. The basis for this article is the preparatory works

\author{
M. A. Hjort ( $\varangle)$ \\ University of Oslo, Karl Johans gate 47, 0162 Oslo, Norway \\ e-mail: m.a.hjort@jus.uio.no


to Nordic procedural acts and codes the last three centuries, and the question is what sources of inspiration the Nordic countries have used in designing their procedural law and how this use fits with the idea of a Nordic procedural law.

\section{Legislation and Society}

All modern societies have legislation that regulates the citizens' rights and obligations and how the citizens can claim these rights and obligations. The legislator will always try to adapt the legislation to the society in which it operates, and this strong connection between the legislation and the society has significance in several contexts. ${ }^{1}$

First, the connection between the legislation and the society explains why societies that are similar politically, geographically and culturally often have legislation with many common features. The Nordic countries share-among other things-a common view on democracy, welfare, social security and equality. ${ }^{2}$ The five countries also shares a common history. Unions in different constellations have led to common legislation in periods, ${ }^{3}$ or legislation designed separately for the individual countries of the union but by the same legislator. ${ }^{4}$ The shared history explains the similarities in the societies and, at the same time, gives the Nordic countries a common legal platform to develop their legislation.

Second, the connection between legislation and society has an impact when one of the two elements changes. Changes in society lead to a need for changes in legislation, and changes in legislation change society. As both society and ideas on improvement of the legislation are constantly evolving, there will regularly be a need and desire to make changes in or reforms to the legislation. The question is how these changes should be designed and in what direction the changes are going. Legislators will practically never draft new legislation without looking at how other jurisdictions regulate the issue. The design of the changes comes down to the issue of sources of inspiration.

\footnotetext{
${ }^{1}$ See, e.g., Knoph (1998), p. 1 and Mathiesen (2011), pp. 26 ff.

${ }^{2}$ Backer (2018), p. 14.

${ }^{3}$ Such as for Sweden and Finland in the period of 1154-1809.

${ }^{4}$ As in Norway and Iceland in the period 1260-1450, see Sigurðsson (2015), p. 17, and DenmarkNorway in the period $1660-1814$.
} 


\section{Objectives of the Procedural Reforms}

\subsection{First Wave of Reforms: Establish a Justifiable Basis for the Judgment}

Before initiating a procedural reform, the legislator must be clear about the objectives of the reform. The goals of the Nordic procedural reforms have varied throughout history. Many of the reforms have also had several objectives. ${ }^{5}$ The survey of procedural reforms in the Nordic countries shows that the objectives of the reforms coincide, and over time simultaneously change. In the further analysis, it will continuously be examined which sources of inspiration were the basis for the changes in the litigation.

The Nordic reforms of procedural law from modern history can roughly be divided into three periods: one in the beginning of the twentieth century, one at the turn of the twenty-first century, and one at the beginning of the twenty-first century. In the first wave of Nordic procedural reforms, at the beginning of the twentieth century, there were two objectives explicitly stated. The first objective was to obtain a procedural arrangement that established a justifiable basis for the decisions, and the second was to reduce the processing time. The court proceedings in all five Nordic countries were based on three codes: Christian V's Danish and Norwegian Codes from 1683 and 1687 and the Swedish Code of 1734. Finland was in union with Sweden when the Code of 1734 was passed, and thus the code became applicable in Finland as well. Iceland was part of Norway when Norway entered into union with Denmark in 1660, and the rules of procedure of Christian V's Norwegian Code of 1687 became applicable to Iceland. ${ }^{6}$ The three codes contained older practices and provisions and represented regulation from the 'Ancient Regime'.

Denmark, Norway and Sweden all made attempts to reform the procedural law during the nineteenth century, but, except from the Norwegian Criminal Procedure Act from 1887, none of the attempts succeeded. ${ }^{8}$ The Norwegian Criminal Procedural Act succeeded probably due to the political desire to introduce the jury system. ${ }^{9}$ The jury system was sourced from England and partly Scotland, and important elements in the new procedure included orality, immediacy, free assessment of evidence, the introduction of a prosecution authority and separation of the executive and the judiciary authority. ${ }^{10}$

\footnotetext{
${ }^{5}$ Uzelac provides an overview of basic objectives for civil procedure; see Uzelac (2014), p. 5.

${ }^{6}$ See Arnesen (1762), p. 23. King Fredrik the Fourth's order was announced at the Icelandic parliament in 1719.

${ }^{7}$ Kekkonen (2009), p. 5. See also Robberstad (1971), p. 117 and Andersen (2019), p. 13.

${ }^{8}$ Hjort (2021), Sects. 2.1, 2.2 and 2.4 give a fuller description.

${ }^{9}$ Hjort (2021), Sect. 2.2 gives a fuller description.

${ }^{10}$ Bilag III to Dok. no. 1 (1885), p. 467. The changed view of the assessment of evidence is further discussed in Skyberg (2019).
} 
Finland also drafted several proposals for reform of the procedural law, and some were adopted. None of these, however, changed the overall problems in the procedure. ${ }^{11}$ There were several reasons why the legislative processes were stranded, but the main problems were lack of faith in the radical changes of the existing procedures, questions on financing and how the transition from the old to the new legislation should be conducted. ${ }^{12}$

At the end of the nineteenth century, the situation became more and more critical. The reform committee to the Norwegian Civil Procedure Act stated that a 'main shortcoming of our procedural system is its imperfect ability to bring about the true matter of the case'. ${ }^{13}$ A pervasive problem with the litigation was the use of writing. ${ }^{14}$ The decisions were subject to a written examination, which meant that all testimonies had to be protocolled. Questions to the witnesses had to be prepared in advance, and there was no possibility to ask follow-up questions without calling the witness again. As a result, ambiguities and an increased risk of a defective decision base could easily arise.

To establish a justifiable basis for the decisions, the solution to fulfil the first reform objective was to introduce oral proceedings. The Norwegian Criminal Procedure Act was the first modern Nordic act based on oral proceedings, and it was an important source of inspiration for the following acts in Nordic countries. This was mainly due to the fact that the Norwegian Criminal Procedure Act had already been enacted in 1887 and that the legal solutions in this act were a novelty. ${ }^{15}$ The wave of procedural reforms came at the beginning of the twentieth century: the Norwegian Civil Procedure Act was passed in 1915; the Danish Code of Judicial Procedure followed in 1916 and the Swedish Code of Judicial Procedure was enacted in 1942.

The change from written proceedings to oral proceedings with immediate submission of evidence was primarily sourced from the German and Austrian procedural legislation in Denmark, Sweden and Norway. ${ }^{16}$ Both the Norwegian Civil Procedure Act and the Danish Code of Judicial Procedure were enacted before the First and

\footnotetext{
${ }^{11}$ Hjort (2021), Sect. 2.5 gives a fuller description.

${ }^{12}$ Regarding Norway, see Hearing in Odelstinget 5-7 July 1915, pp. 1451-1499 and Hjort (2007), pp. 30 ff., regarding Sweden, see SOU 1944:10, pp. 28 ff., regarding Denmark, see Bilag VII Retspleje-Reformen. En Oversigt (1901), pp. 3217-3226.

${ }^{13}$ Ot.prp. no. 1 (1910), p. 9 (My translation). For a corresponding view in the Danish preparatory work, see Bilag VII Retspleje-Reformen. En Oversigt (1901), pp. 3231-3232.

${ }^{14}$ This applies at least for Denmark, Norway, Sweden and Finland. Unfortunately, it has not been possible to find more detailed information about Iceland's procedural law in the nineteenth century and the beginning of the twentieth century; however, since Iceland was governed by Denmark for a large part of this period, it is natural to assume that Icelandic procedural law had some of the same problems as in Denmark.

${ }^{15}$ See the Norwegian criminal procedure highlighted in Danish preparatory works: Bilag VII Retspleje-Reformen. En Oversigt (1901), pp. 3235-3236, questions regarding processing of the Police Affairs, pp. 3317-331, and Excerpt from the Norwegian criminal procedure statistics, pp. 3343-3352.

${ }^{16}$ Denmark: see for example Bilag II to Udkast til Lov om den borgerlige Retspleje (1901), pp. 2725, 2729, 2731, 2734, 2751, 2785, 2800-2801, 2806-2807 and 2809, Sweden: see SOU 1926:33, pp. 7 ff. and pp. 18 ff., Norway: see Udkast (1908) Bilag III to Ot.prp. 1 (1910), p. 79. Three major acts
} 
Second World Wars. The Swedish Code of Judicial Procedure was enacted in 1942, in the middle of the Second World War, and having German and Austrian legislation as sources of inspiration was perceived as problematic. ${ }^{17}$ Attempts were therefore made to tone down the importance of the German and Austrian influence in the legal literature. ${ }^{18}$

Iceland and Finland did not reform their procedural law during this first wave of procedural reforms. Finland was part of Russia from 1809 to 1917, and after the Second World War, the financial resources needed to modernise the judicial procedure were absent. ${ }^{19}$ Iceland became fully independent in 1944, but even though the civil procedure was reformed in 1936 and the criminal procedure in 1951, this did not meet the legislative needs. In the following decades, Iceland continued to reform their procedural acts. ${ }^{20}$

Oral proceedings were also the answer to the second objective of the procedural reforms, so as to reduce the processing time. In the eighteenth and nineteenth centuries, the Nordic countries had court proceedings that took a disproportionately long time. ${ }^{21}$ This was mainly because of written proceedings, ${ }^{22}$ as it was timeconsuming to write down the basis for the judgment. With the transition from written to oral proceedings, this improved significantly. ${ }^{23}$ In Sweden, the oral proceedings was a remedy for the constant need for adjournment. In civil cases and criminal cases brought by an individual party, there were hardly any preparations made in the cases before the main hearing, except for the statements of claim being submitted, which were often incomplete. ${ }^{24}$ The Swedish reform committee, The Judicial Procedure Commission, stated that the solution was a public procedure based on orality and immediacy, and with free evaluation of evidence. ${ }^{25}$

An interesting observation is that the solutions were sourced from the same jurisdictions. In addition to examining the development of procedural law in the other Nordic countries, both German and Austrian procedural law became important sources of inspiration for the development of new Nordic procedural law. German law was an important source of inspiration in several areas of law and a channel for the influence of Roman Law-based terminology and systematisation. ${ }^{26}$ However,

were adopted simultaneously in 1915: The Civil Procedure Act, the Courts of Justice Act and the Enforcement of Claims Act.

${ }^{17}$ Bellander (2017), pp. $52 \mathrm{ff}$.

${ }^{18}$ See Gärde (1931), p. 3 and Schlyter (1934), p. 530, among others.

${ }^{19}$ Letto-Vanamo (2012), p. 91.

${ }^{20}$ Hjort (2021), Sect. 2.3 gives a fuller description.

${ }^{21}$ Regarding Finland, see Kekkonen (2009), pp. 5 and 12. Regarding Norway, see Ot.prp. no. 1 (1910), p. 7.

${ }^{22}$ Regarding Denmark, see Bilag VII Retspleje-Reformen. En Oversigt (1901), pp. 3261-3262.

${ }^{23}$ Regarding Sweden, see SOU 1926:32, pp. 15-23.

${ }^{24}$ SOU 1926:31, p. 21. See also Hjort (2021), Sect. 2.4.

${ }^{25}$ SOU 1926:31, pp. 15-26 and SOU 1926:32, pp. 18-22. Björne (1998), pp. 415 ff. also addresses the Swedish debate on free assessment of evidence.

${ }^{26}$ Letto-Vanamo (2012), p. 90. 
the choice of German and Austrian procedural law as sources of inspiration for the Nordic procedural reforms probably has a more concrete explanation. The Nordic countries had identified the problems they were facing in this area, and German and Austrian procedural law could point to reforms that offered solutions to those particular problems. The results of Franz Klein's civil procedure reform in Austria in 1895 must have seemed convincing in Norway, Denmark and Sweden, and the use of a jury made it necessary to have oral procedure in criminal cases as well. The Nordic countries thus moved in the same direction, not because it was a common Nordic idea of how procedural law could be developed but because they faced the same problems and looked to the same sources of inspiration in the process of solving them.

\subsection{Second Wave of Reforms: Secure a Fair Trial}

The second wave of procedural reforms took place at the turn of the twenty-first century and was an adjustment of the effects of the first reforms. The proceedings were still oral and immediate, but the view of these principles became more nuanced, and new elements were adapted to the procedure. It appeared to be a common goal in the Nordic countries to achieve efficient proceedings, but not to the detriment of a fair trial. The Convention for the Protection of Human Rights and Fundamental Freedoms was enacted in 1950 and entered into force in 1953, but it was not until the 1980s and 1990s that the Nordic countries realised that the Convention set the framework for procedural legislation through Article 6 on the right to a fair trial. The convention had an impact on the objectives for the reforms and how the procedural litigation was designed. ${ }^{27}$

As mentioned, the Norwegian criminal procedure was enacted in 1887 , and the need for reform arose earlier than with the other Nordic procedural acts. A reform committee was set up in 1957, and thus the reform of the criminal procedure in Norway was ahead of the second wave of Nordic procedural reforms. The mandate pointed out several issues that the committee should address. ${ }^{28}$ Like the procedural reforms in the second wave of reforms, the reform committee stated that the procedure should continue to be oral and immediate. The main question was whether Norway should continue with a system including lay judges. ${ }^{29}$ After a comprehensive reform process, a new Criminal Procedure Act with jury trials was passed in $1981 .^{30}$

Finland and Iceland joined the second wave of procedural reforms at the turn of the twenty-first century, but with a different starting point than the other Nordic countries. The two countries had a goal of establishing a procedure that was both efficient and fair, but in addition, the procedural legislation had to fulfil the objectives

\footnotetext{
${ }^{27}$ The best example is probably the first article in the Norwegian Dispute Act stating the purpose of the act. The article has many similarities to Article 6 in the Convention.

${ }^{28}$ NUT 1969:3, p. 71.

${ }^{29}$ NUT 1969:3, p. 81 and Ot.prp. no. 35 (1978-79), p. 7 and pp. $13 \mathrm{ff}$.

${ }^{30}$ Hjort (2021), Sect. 3.6 gives a fuller description.
} 
that the other three Nordic countries had established many decades earlier. Although Iceland regularly had made changes in legislation, the need for a pervasive reform was still present at the end of the twentieth century. A case for the Court of Human Rights in 1987 gave Iceland a push to reform their procedural law, and in 1989, Iceland's parliament appointed a reform committee. ${ }^{31}$ The result was a complete review and reform of both civil and criminal procedure with acts from 1989 and 1991. ${ }^{32}$ The Criminal Procedural Act from 1991 has already been reformed, and the current Criminal Procedural Act was passed in 2008, followed by an act on the special prosecuting authority. ${ }^{33}$

Finland based their proceedings on the old rules in the Code of 1734 with an 'oral-documentary' procedure until the $1990 \mathrm{~s},{ }^{34}$ when comprehensive legislation was made to meet today's expectations. The procedure in the lower courts was reformed in 1993 and 1997 for civil and criminal cases, respectively. In 1998, the appeal court was reformed in the same line. ${ }^{35}$ All the reforms were made within the framework of the Code of 1734, and the similarity to Swedish legislation was thus still striking. Just as in Iceland, Finland had a need for adjustments of their reforms, and improved procedural litigation was enacted in 2003 and 2006. ${ }^{36}$ Most Finnish preparatory work refers to foreign law, especially Swedish, Norwegian and Danish law. Sometimes it refers to English, German and French law, ${ }^{37}$ but the 'template' seems to be based on Nordic procedural law. ${ }^{38}$

Sweden, Denmark and Norway followed closely after Iceland and Finland, and the three countries all set up reform committees in 1998 and 1999. For Norway, this was only a matter of reforming the civil procedure, since the criminal procedure had already been reformed, ahead of the second wave of reforms. Sweden implemented several reforms after the entry into force of the Swedish Code of Judicial Procedure in 1942 and these reforms put Sweden ahead of the second wave of procedural reforms in many ways. ${ }^{39}$ Still, all three committees were instructed to examine how oral and written proceedings should be weighed against each other to make the procedure more efficient, while still ensuring that it would satisfy current rule of law requirements. ${ }^{40}$

\footnotetext{
${ }^{31}$ Case of Jón Kristinsson v. Iceland, no. 12170/86, Commentary to Act. No. 92/1989. Hjort (2021), Sect. 3.2 gives a fuller description.

${ }^{32}$ See Commentary to Act No. 92/1989, Commentary to Act No. 19/1991 and Commentary to Act 91/1991.

${ }^{33}$ See Act No. 88/2008 and Act No. 135/2008.

${ }^{34}$ Ervo (2009), p. 55.

${ }^{35}$ See L 1056/1991, L 689-690/1997 and L 165/1998.

${ }^{36}$ See L 768/2002, L 381/2003 and L 244/2006.

${ }^{37}$ See for example RP 190/2017, pp. 10-12 and RP 32/2001, pp. 13-14.

${ }^{38}$ Hjort (2021), Sect. 3.3 gives a fuller description.

${ }^{39}$ Hjort (2021), Sect. 3.4 gives a fuller description.

${ }^{40}$ See SOU 2001:103, pp. 384-385, SOU 2003:74, pp. 55 ff., SOU 2005:117, pp. 43 ff., Justitsministeriet (1998), pp. 1-3 and NOU 2001:32, p. 140-141. See also Lindblom (2000).
} 
The efficiency object led to several changes. One common change was an increased use of written elements in the proceedings. In the reforms from the beginning of the twentieth century, the requirement of orality was introduced almost without exceptions to ensure the transition from written to oral proceedings. In the second wave of reforms, the legislatures could allow themselves to open up for some written elements without a fear of relapse back to written proceedings. One implication of this was a change in the presentation of written evidence in court. Whereas previously there had been a requirement for written evidence to be read in the oral hearings, following the change it was sufficient to point out what the evidence should prove. ${ }^{41}$

Another change was the shift to a focus on a more flexible procedure. More flexible procedural rules provide proceedings that are more efficient, because the proceedings can be adapted to the individual case. In Denmark, this resulted in a proposed scheme where the procedure contained a number of standard elements that could be combined according to the individual case's needs. ${ }^{42}$ Another way of making the procedure more flexible is to establish different procedural tracks. Both Denmark and Norway introduced a simplified procedure for cases with a claim of limited value..$^{43}$ The small claims track is less expensive than the general track and thus allows for judicial proceedings of cases that were previously resolved outside the court system. The flexibility in the procedural rules requires active judges who adapt the proceedings to the individual case. In both Denmark and Norway, the importance of active case management was emphasised in the preparatory works. ${ }^{44}$ The Norwegian committee referred to Denmark and Sweden as important sources of inspiration for drafting the Dispute Act ${ }^{45}$ but the Norwegian survey differs from the other Nordic countries' procedural reforms by clearly emphasizing England as an important source of inspiration. ${ }^{46}$ Still, the main objectives coincide.

A third common change was the increased use of technology. Like Finland, all three countries opened, inter alia, the possibility of remote interrogations and main hearings through video conferencing ${ }^{47}$ However, the main rule was still that parties should be present or represented physically during the main hearing. Opening up the

\footnotetext{
${ }^{41}$ See SOU 2001:103, p. 183, NOU 2001:32, pp. 758 and 978, and KBET 2001 no. 1401, pp. 293 ff.

${ }^{42}$ KBET 2001 no. 1401, p. 271.

${ }^{43}$ The limit for using this simplified procedure is, however unequal in the two countries. In Denmark, the small claims procedure is offered for claims less than 50,000 DKK (app. $6700 €$ ), while the Norwegian limit is set at 250,000 NOK $(\sim 25,000 €)$.

${ }^{44}$ NOU 2001:32, pp. 238 ff., KBET 2001 no. 1401, pp. 269 and 315 ff. Denmark has produced several preparatory works in connection with procedural reforms. Hjort (2021), Sect. 3.5 gives a fuller description.

${ }^{45}$ The Danish consideration KBET 2001 no. 1401 is mentioned in NOU 2001:32, pp. 135, 295, 682 and 841. Other Danish considerations are also pointed out in the Norwegian consideration; see NOU 2001:32, pp. 327-330.

${ }^{46}$ NOU 2001:32, pp. 181-184 and pp. 330-332.

${ }^{47}$ Finland: RP 83/2001, pp. 15-20, Denmark: KBET 2001 no. 1401, p. 61 and pp. 363-368, Sweden: SOU 2001:103, pp. 83 ff. and Norway: NOU 2001:32, pp. 242-243 and p. 608.
} 
possibility of handling the case without all actors being physically present required the installation of necessary technical equipment. Nevertheless, the Nordic courts took their first steps towards a legal procedure based on modern ICT. Sweden was ahead of the other Nordic countries with the recording of all testimonies from the district courts for use in a possible appeal. ${ }^{48}$

\subsection{Third Wave of Reforms: Adapt the Proceedings to the Individual Case}

Sweden, Norway and Denmark had their reformed procedural legislation passed in, respectively, 2005, 2005 and 2006. ${ }^{49}$ By 2008, these reforms were all in force, and at that point, all the Nordic countries had reformed their procedural legislation. One might think that the Nordic countries then would not do changes in their procedural legislation for a while, but in reality, the opposite occurred. The procedural rules have already undergone another procedural reform after the reforms at the turn of the twenty-first century. By adapting the procedural law to social development and the use of technological tools, the Nordic countries have taken a further step towards an ideal balance between fairness and efficiency in trials.

Sweden evaluated its reform from 2005 in 2011-2012 and concluded that the use of technology in courts had been a success. ${ }^{50}$ The legislator decided to make further use of the court's audio and video recording by not only recording testimonies during the main hearing but also taking evidence outside the court session. Inter alia, this would be convenient in cases when the main hearing is postponed and parties and witnesses have appeared to provide testimonies. ${ }^{51}$ Several preparatory works have been conducted to survey the possibility of making the procedure more effective and flexible. ${ }^{52}$

Iceland has not initiated any major reform efforts that have led to new acts, but, like both Finland, Sweden and Denmark, a number of amending laws. ${ }^{53}$ Regarding use of audio and video recordings, Iceland has followed Sweden's example, and amendments were introduced in the Icelandic Criminal Procedure Act and the Civil Procedure Act in 2019, regulating the use of recordings from the district courts. ${ }^{54}$

\footnotetext{
${ }^{48}$ Prop. 2004/05:131, p. 105. See also SOU 2008:93. In Sweden, the use of ICT started already during the second wave of procedural reforms. Hjort (2021), Sect. 3.4 gives a fuller description.

${ }^{49}$ Regarding Sweden, see Lag 2005:683; regarding Norway, see Lov-2005-06-17-90; regarding Denmark, see Lov 2006-06-08 no. 538.

${ }^{50}$ SOU 2012:93, p. 265, Prop. 2015/16:39, pp. 20 ff.

${ }^{51}$ Prop. 2015/16:39, p. 39. Hjort (2021), Sect. 4.2 gives a fuller description.

${ }^{52}$ See f.ex. SOU 2013:17 and SOU 2018:44.

${ }^{53}$ Hjort (2021), Sect. 4.4 gives a fuller description.

${ }^{54}$ Lög no. 76 25. júní 2019, in force 5 July 2019.
} 
In Denmark, the Court Administration adopted the Danish Court's digitisation strategy in 2014, with the expressed goal of being able to handle the whole proceeding in civil cases digitally. ${ }^{55}$ Paper vouchers and postal mails in civil proceedings disappeared as early as in 2016. Today, through a digital self-service portal, one can file a case, pay court fees, get information and guidance through a new text library and communicate with others. ${ }^{56}$ In Norway, the Norwegian Courts Administration established a web portal for the exchange of case information and documents in disputes, judgments, and filing fees in both civil and criminal cases. ${ }^{57}$ However, compared to Denmark, Norwegian procedural legislation is a bit behind on this point. ${ }^{58}$ The Norwegian Criminal Procedure Act from 1981 is about to be reformed, and the proposals for a new criminal procedure act will modernise the criminal justice system, but the committee has a somewhat more cautious approach in digitizing the procedure compared to, for example, Sweden..$^{59}$

Finland has had 41 major and minor amendments related to the Code of 1734 since the last criminal procedure reform came into force in $2006 .{ }^{60}$ These changes can be said to fit one of two purposes; changes made to structure and clarify the legislation, or changes made to make the procedure more flexible and better adapted to a constantly evolving society. ${ }^{61}$ As part of the latter purpose, technological changes like serving by telephone and the use of video links as a substitute for physical presence result in a more efficient procedure. ${ }^{62}$ Digital submission of statements of claim is also mandatory in Finland in civil cases, and in criminal cases the ability to use video links at the hearings was expanded in $2018 .{ }^{63}$ The defendants now have the opportunity to follow the whole hearing via video link and participation via video link is equal to physical presence. All these changes are made to adapt the proceedings to the individual case and thus make the proceedings more efficient, and technological tools are frequently used in this respect.

The goals a country sets for its procedural reform represent a way to settle its status. They communicate how far the country has developed its procedural law and in what direction the country wants to develop. Although it is a gradual transition, a procedure that establishes a justifiable decision base in the case can be considered a first-generation goal, while real access to court litigation for small claims is a typical second-generation goal. Making use of digital technology to make proceedings even more efficient and streamlined is a goal of a third-generation procedure

\footnotetext{
${ }^{55}$ LFF-2015-10-07 no. 22 General remarks Sect. 2.

${ }^{56}$ LFF-2015-10-07 no. 22 General remarks Sect. 2. Hjort (2021), Sect. 4.3 gives a fuller description.

${ }^{57}$ So far, the portal is only accessible to attorneys and courts.

${ }^{58}$ The Dispute Act was evaluated in 2013, and the efficiency and productivity of the courts was examined. No amendments were proposed based on the evaluation report; see Report (2013).

${ }^{59}$ NOU 2016: Sect. 4.5 gives a fuller description.

${ }^{60} \mathrm{~L} 244 / 2006$. Search at finlex.fi accessed 28.5.2020.

${ }^{61}$ Hjort (2021), Sect. 4.1 gives a fuller description.

${ }^{62} \mathrm{~L} 362 / 2010$ and L 422/2018.

${ }^{63}$ Finland: RP 190/2017, p. 26 and RP 200/2017, p. 29 (The latter amendment came into force 1.6.2018).
} 
reform, and time will tell whether the corona pandemic has acted as a catalyst for a fourth generation of procedural reforms. Some objectives, in particular the desire for time-efficient proceedings, continue as goals in all generations, but the instruments used change. Central to this article is the fact that the goals set for procedural reforms also are crucial for the choice of sources of inspiration.

\section{Choice of Sources of Inspiration}

Procedural law is often viewed as a national matter, and legislative committees preparing considerations and act proposals in procedural law are not obligated to survey foreign law for potential sourcing. Nevertheless, this is common, especially in considerations with overall importance. Presenting foreign law implies an appraisal of which country's legislation it is of interest to survey. Several factors can be decisive.

One important factor is the similarity between the legal system potentially sourced from and the legal system to be reformed. It is common to look to countries with similarities, which in practice are countries within the same legal tradition. ${ }^{64}$ The Nordic countries are often considered a separate legal family, and this itself gives a law committee in a Nordic country a reason to survey the other Nordic countries in drafting an act proposal. The Nordic legal family is limited in size, and if one adhered strictly to the categories established in comparative law theory, access to sources of inspiration would be narrow. However, the Nordic countries have similarities with both common law and civil law. Traditionally, the Nordic legal family is considered to be closer to civil law than common law, and the discussion above clearly shows a tendency to both refer to and make use of foreign law from civil law countries rather than common law countries. An example is Franz Klein's Austrian procedure reform from 1895, which was an important source of inspiration for several of the Nordic countries. ${ }^{65}$ Presumably, repeated use of sources of inspiration from the same legal family strengthens the connection with this family. This is perhaps why reactions arose when elements of English law were used as a central source for the Norwegian Dispute Act, without examining the relevant civil law countries more thoroughly. ${ }^{66}$

However, the choice of sources of inspiration is not limited to countries in legalfamily relationship, and there are many historical examples of law being sourced without any legal connection between the two legal systems. The reason is often

\footnotetext{
${ }^{64}$ This again assumes that this is a voluntary reception.

${ }^{65}$ Regarding Denmark, see Bilag II to Udkast til Lov om den borgerlige Retspleje (1901), p. 2725; regarding Sweden, see SOU 1926:33, pp. 45-47 and pp. 99-101; and regarding Norway, see Utkast (1908) Bilag III to Ot.prp. 1 (1910), p. 79. Based on Norwegian preparatory work, it seems that Finland's proposal for reform of the judicial system from 1901 has used Austrian procedural law as a source of inspiration.

${ }^{66}$ Robberstad (2004), pp. 585 ff.
} 
that the recipient country has not chosen this sourcing itself. ${ }^{67}$ Even law introduced with force will also, over time, attach itself locally and interfere with local law. Two descriptive examples are the influence of Canon and Roman law in most of Europe. In Nordic countries in modern times, however, the choice of sources of inspiration and reception of foreign law is based on the legislator's own preference.

Even based on voluntariness, sources of inspiration are not chosen solely on the basis of legal family relationships. In consideration of the Norwegian Civil Procedure Act of 1915, the committee clearly expressed another important factor:

In developing the draft of a new procedure act for Norway, there must of course be a ques-
tion of seeking a model in foreign procedural acts and drafts, and of utilizing the experience
gained in other countries. Without being bound to commit to a certain foreign legislation, the
Committee has-like in Denmark and Finland-sourced inspiration where one has previ-
ously had a similar condition as us, and where the new acts have substantially pursued the
same legal tendencies as those leading this draft act. This especially applies to the German
and Austrian Civil Procedure Acts, and the draft of a new procedure act for Norway has
preferably joined the Austrian model because it largely avoids the disadvantages that have
been shown to adhere to the French and German procedural law and, in general, seems to
show extremely favourable practical results. ${ }^{68}$

The above quote explains why Austrian law was an important source of inspiration. Klein's reform replaced a written and highly formalised procedure with an oral and immediate procedure based on free assessment of evidence. ${ }^{69}$ As described above, this led to the court having a more justifiable basis for its decisions. Another effect of the procedural reform was increased efficiency. ${ }^{70}$ Klein's reform was a solution to problems with which many procedural schemes in Europe struggled, and it became an important source of inspiration in many countries. ${ }^{71}$

The choice of Austria as a source of inspiration in the beginning of the twentieth century was a simple choice. The two main objectives for the Nordic reforms were to achieve procedural legislation that established a justifiable basis for the decisions and to reduce the processing time. Austrian procedural rules could fulfill both these objects. In addition, Austria was a jurisdiction with features that the Nordic countries could recognise. Being a jurisdiction from the civil law tradition, Austria had courts similar to the Nordic, and the similarities made it easier to convince critics that the great upheaval of the procedural legislation was feasible.

There are examples of choices of sources of inspiration across legal cultures and families, but there are also challenges associated with such choices. ${ }^{72}$ A procedural solution that works well in one country can have a completely different effect in a country with a different legal culture, even if the rules are concurrent. As described

\footnotetext{
${ }^{67}$ Mousourakis (2013), p. 225. Mousourakis mentions several reasons for reception of foreign law; e.g., because of conquest, colonial expansion or the political influence of the state whose law is adopted.

${ }^{68}$ Udkast (1908) Bilag III to Ot.prp. 1 (1910), p. 79, my translation.

${ }^{69}$ Hagerup (1899), p. 241.

${ }^{70}$ Hagerup (1899), pp. 305-306.

${ }^{71}$ Uzelac (2014), p. 6.

${ }^{72}$ Mattei (1994), p. 6.
} 
in the introduction, there is a strong connection between legislation and society, and different societies can respond differently to the same rules. Therefore, it is safer to source inspiration from countries with common legal features. ${ }^{73}$

In the legal literature, it is argued that the choice of sources of inspiration can be made based on which procedural scheme gives the best efficiency. Mattei defines efficiency as the rules that gives the lowest transaction costs at all times, and it is emphasised that although legal systems have different rules, this difference does not necessarily have to mean a difference in efficiency. ${ }^{74}$ Different legal systems can develop alternative solutions to the same legal problem, and the solutions can be equally efficient. Efficiency is, as I discussed in Sect. 3.3, a fundamental goal repeated in all generations of procedural reforms, but the assessment that Mattei puts forward probably fits best in the second and third generation of procedural reforms. Moreover, although Mattei talks about legal transplant on a very general basis, it may seem that he is primarily aiming at substantive legal rules. ${ }^{75}$ It remains, therefore, to be seen whether this legal economic reasoning can also be brought forward in the context of procedural law.

As a general summary, the Nordic countries seems to have chosen their sources of inspiration based on two principles: countries with which it is natural to compare and countries that can demonstrate good solutions to the procedural problems that need to be solved. The principles are often used in combination. On a Nordic level, I find it difficult to point to a certain displacement of sources of inspiration over time, but as a general observation, German-speaking countries seems to be less often used. This may be due to political reasons or lack of knowledge of the German language and legislation, or it may simply be because good solutions are found in other places. In any case, a trend that has persisted over time is the Nordic countries' choice to refer to each other.

\section{Use of Sources of Inspiration}

The Nordic countries nearly always consider the other Nordic countries' procedural law in the preparatory work to their procedural reforms. ${ }^{76}$ The review of the Nordic countries' procedural law is often followed by additional selected countries. However, the fact that the preparatory works include a review of foreign procedural

\footnotetext{
${ }^{73}$ Watson (1974), p. 17 emphasise the importance of good systematic knowledge of foreign law before sourcing from it: 'A rule of Swedish law which is successful at home might be a disaster in the different circumstances existing in Scotland; a rule of French law which there works badly might provide an ideal rule for Scotland.' .

${ }^{74}$ Mattei (1994), pp. 11 and 19.

${ }^{75}$ Watson (2001), p. 87 also mentiones the efficiency argument related to amending substantive provisions.

${ }^{76}$ This applies to Danish, Norwegian, Finnish and Swedish preparatory work. The Icelandic preparatory work does not seem to have a tradition of presenting foreign law in a separate chapter. Sources of inspiration will appear in the discussion in the preparatory work.
} 
law is not equivalent to the use of these procedural rules as source of inspiration for developing own procedural rules. A test to examine the actual use of certain foreign rules could be to see if the committee has also referred to the relevant foreign rules in the specific motives for the proposal. There is no guarantee that one will find such references. The question then is what use the Nordic law committees make of the review of foreign procedural law. Is it actually a presentation of sources of inspiration, or are there other reasons for the committee to present such a review?

One explanation may be that it has become a tradition to present a review of foreign legislation in the preparatory work to large procedural reforms and that the committee presents the review on a routine basis to meet this expectation. ${ }^{77}$ However, the review of the Nordic preparatory works gives the impression that the review has a purpose. Although it may seem like a routine, the committee has actively chosen the countries represented and elucidated certain elements from their procedural rules. To argue that the review is only a compulsory item in the consideration and has no intrinsic value would be to underestimate the review.

Another explanation may be that the presentation of foreign law legitimises the committee's suggestions. Instead of using the foreign law as a source of inspiration, the committee can point out the strengths and weaknesses of the solutions chosen in the neighbouring country and, on this basis, justify a proposal. Thus, the foreign law will serve as a basis for comparison.

A third explanation may be that a review of foreign law is presented to put one's own procedural rules into context. Based on the review of preparatory work from the Nordic countries, it may appear that the presentation of procedural law in the Nordic countries is primarily intended for this purpose. ${ }^{78}$

There are certainly examples of law committees being inspired by other Nordic countries and that the committees have used procedural law from other Nordic countries explicitly as a source of inspiration. ${ }^{79}$ However, the main impression is that the review of the Nordic countries' procedural law is primarily made to place one's own legislation in a procedural landscape. The preparatory work does not give the impression that this is being done to explicitly point out a Nordic procedural law community. The basis for the use of inspiration from other Nordic countries simply seems to be the assumption that the other Nordic countries face the same problems as one's own and that one can therefore source from the experiences these countries have gained. Although the Nordic countries are not explicitly used as sources of inspiration, the significance of such contextualisation should not be underestimated. The Law Committee raises awareness of solutions in the Nordic countries, and this may have an impact on the solutions the Committee itself proposes.

\footnotetext{
${ }^{77}$ According to Letto-Vanamo and Tamm (2019), p. 7 a review of the Nordic countries' law 'forms part of the preparatory procedure for new laws in Finland'.

${ }^{78}$ Icelandic preparatory works differ on this point, because they do not give a review of foreign law, but rather mention foreign law where it is explicitly used.

${ }^{79}$ Examples are the reference to Danish and Norwegian legislation in Icelandic preparatory work, see Commentary to Act No. 88/2008, p. 85; the reference to Swedish legislation in Finnish preparatory work, see RP 83/2001, p. 19; and the reference to Danish and Norwegian rules on criminal proceedings in SOU 1926:33, f. ex. pp. 32-33 and pp. 145-146.
} 
So far, I have surveyed the use of sources of inspiration by reviewing foreign legislation in the preparatory works, and this may serve as a base. However, the actual use of sources of inspiration may be far more complex. On one hand, the Law Committee will hardly ever have carte blanche to propose whatever changes they like. The Committee's mandate will usually address a problem to be solved or even a type of solution preferred. These limitations may well affect from which countries it is possible to draw inspiration. On the other hand, the Law Committee does not always address the origin of the source of inspiration, and the source could be more than one solution or a combination of solutions in several countries. When writing the preparatory works, the Law Committee's priority is not necessarily to highlight the origin of the source of inspiration. Moreover, the more complex is the background for the source, the more difficult it is to reveal the 'real' source of inspiration.

All these factors affect the picture the preparatory works give concerning the use of sources of inspiration, making it difficult to draw clear conclusions from the use of sources of inspiration regarding the question of whether Nordic Procedural Law exists as a phenomenon. The introduction of class action rules in Norwegian law may serve as an example of mixed sources of inspiration. The Norwegian Civil Procedure Committee's mandate clearly stated that one of the Committee's tasks was to study and submit proposals for rules on class actions. At that point, Sweden was preparing to adopt rules on class actions, and the Norwegian preparatory works present the Swedish solution. Even though American legislation was the original source, the Swedish solution was of decisive importance for the final design of the Norwegian rules. ${ }^{80}$ One may argue that the Norwegian rules were inspired by the US rules on class actions and that this indicates an open approach to the use of sources of inspiration. However, the same example may be used to argue for a Nordic consciousness when implementing legal elements from non-Nordic countries. The key point in this context is to emphasise that there are many nuances in the use of a source of inspiration, and the Nordic countries' use of sources of inspiration does not necessarily give a clear answer to the question of whether Nordic Procedural Law exists.

\section{The 'Nordic-Ness' in the Nordic Procedural Law}

Political and cultural ties bind the Nordic countries together and form the basis for the extensive legal cooperation within the Nordic countries. ${ }^{81}$ Over more than 100 years, joint Nordic acts have been made in fields like purchases, agreements, money claims, intellectual property rights, torts, citizenship and several parts of family law. The Nordic countries also signed the Helsinki agreement in 1962, in which one of the

\footnotetext{
${ }^{80}$ Ot.prp. no. 51 (2004-2005), pp. $320 \mathrm{ff}$.

${ }^{81}$ Letto-Vanamo and Tamm (2019), pp. 2-5 discusses this topic.
} 
main objectives was a 'wish to implement uniform provisions in the Nordic countries in as many respects as possible' ${ }^{82}$

Procedural law has, however, been regarded as a national matter, and history shows only a few examples of legal cooperation. ${ }^{83}$ There was a modest attempt at legal cooperation in 1830, when the Norwegian law committee drafting a criminal procedure act went to Stockholm to discuss the topic with the Swedish law committee drafting a similar act. The Norwegian committee returned home and imparted that the meeting had been successful, stating that ' $[\mathrm{b}]$ oth sides have communicated to each other several remarks that will be of considerable use during the future processing of the draft ${ }^{84}$ However, the meeting did not result in any further cooperation, and neither of the drafts from the committees resulted in a new procedural act or amendments to the current legislation.

In modern times, legislative cooperation in the field of procedural law has been limited to joint meetings of law committees that happen to be working on similar reforms at the same time. For example, the Norwegian Civil Procedure Committee, the Danish Judicial Council and the Swedish Law Committee met in the period of 1999-2001 while they were all working to reform the procedural law. ${ }^{85}$ The Norwegian Justice Department's law department also organised a two-day seminar with participation from all five Nordic countries and from England (Lord Woolf). ${ }^{86}$ However, these meetings seem to have led to nothing more than knowledge of what the other law committees were working on.

Regarding Nordic legislative cooperation, Backer states that it is of great importance whether the EU has competence on the issue or whether the issue falls outside the competence of the EU. ${ }^{87}$ Procedural law falls within the competence of the EU but outside the scope of the EEA Agreement, and therefore a Western-Nordic cooperation could be envisaged (i.e., between Iceland, Norway and Denmark) ${ }^{88}$ However, the conclusion so far is clear: the Nordic legislative cooperation is no source for inspiration of Nordic procedural law.

Without legislative cooperation and with varying use of the other Nordic countries' procedural law as a source of inspiration in the formulation of procedural reforms and major legislative changes, cf. previous chapter, one can wonder if there is a Nordic community within the procedural law at all. Is the 'Nordic model' covering the procedural law?

The review of legislation in the five Nordic countries shows that procedural law in the Nordic countries has many common features, but common historical, cultural

\footnotetext{
${ }^{82}$ LOV-1962-03-23 no. 2, preamble.

${ }^{83}$ Letto-Vanamo and Tamm (2019), p. 10 argues that the lack of legislative cooperation in procedural law is due to the fact that the legislation is formed as a code.

${ }^{84}$ Departements-Tidende (1830), p. 573.

${ }^{85}$ NOU 2001:32, p. 85.

${ }^{86}$ NOU 2001:32, p. 85 .

${ }^{87}$ Backer (2018), p. 37

${ }^{88}$ Criminal law and procedural law are covered by the Danish reservation. Backer (2018), p. 37.
} 
and social features can explain this. ${ }^{89}$ It is not surprising that countries with many similarities choose the same solution when reforming their legislation. But is the similarity an active and conscious attitude towards the Nordic countries as a legal community?

Backer describes the Nordic model as follows:

Value-sharing and similarities in social and natural conditions in the Nordic region help to form the platform for a Nordic model for how society should be organized. Fundamental to the Nordic countries is a system of governance [including elements] such as democracy and the rule of law. Each individual must be equal. Freedoms and rights for the individual are combined with community solutions that express solidarity in society and with measures to protect weak groups. The Nordic model also allows for variations and nuances between the different countries, and this is expressed in different ways, both in legal thinking and legislation and in working life and leisure in the Nordic countries. ${ }^{90}$

The Nordic countries' basic common features and common historical starting point prepare the ground for similar legislation. When choosing sources of inspiration for drafting new legislation, this review shows that sourcing from the other Nordic countries is of first preference. This tendency is pervasive in preparatory work to procedural legislation in all the Nordic countries. In my opinion, this is not because the Nordic countries 'happen to' have many similarities, but because these countries are legally entitled as a family. Only after presenting a review of the solutions in the Nordic legal family do the committees survey other countries, primarily in Europe.

Furthermore, although the importance of the other Nordic countries is not always visible in the specific motives for proposal, this does not mean that the other Nordic countries have lost their position as central sources of inspiration for Nordic countries' procedural law. The use of other Nordic countries as a source of inspiration can also take place in less visible forms. By being aware of the solutions chosen in the other Nordic countries and the experiences they have gained, the reforming country is able to place itself in a procedural landscape, without explicitly expressing this in the preparatory work for the specific provisions. Joint meetings and seminars with the other Nordic countries, like those mentioned above, are efficient tools to source inspiration in a more informal way. However, from an academic point of view, this procedure is challenging because the source of inspiration is difficult to trace.

Another challenge when researching the 'Nordic-ness' in the Nordic procedural law is that of the obvious differences and variations between the procedural systems and choice of sources of inspiration. However, as Backer emphasises, the Nordic model allows for variations and nuances between the Nordic countries. Thus, nontraditional choices, such as the use of England and the United States as sources of inspiration for the Norwegian Dispute Act, do not undermine the family ties between the Nordic countries. Both the linguistic and the cultural community contribute to strengthening the relation, and this community does not disappear because of sourcing outside the Nordic region.

\footnotetext{
${ }^{89}$ Nylund and Sunde (2019) elaborates on this topic.

${ }^{90}$ Backer (2018), p. 14, my translation.
} 
The Nordic perspective in procedural law also appears in other ways. Through Nordic forums, representatives from the Nordic countries meet regularly and maintain the community through academic lectures and discussions. ${ }^{91}$ In the context of research, a Nordic community is visible through doctoral dissertations in Nordic languages, where a representative from another Nordic country participates in the dissertation committee. Moreover, in assessments for academic positions, it is common to include a representative from another Nordic country in the assessment committee. The Nordic procedural law community is also visible in the law itself. In case law, there are many examples of bringing in procedural views from the other Nordic countries when national legal sources fall short, ${ }^{92}$ and in the procedural literature there are references to legal solutions in other Nordic countries. ${ }^{93}$ Not least, several publications present comparative discussions on Nordic procedural law, and this interest in the Nordic commonalities within procedural law is in itself a manifestation of Nordic procedural law as a community. This book also strengthens this impression. ${ }^{94}$

\section{References}

Aarli R, Hedlund M-A, Jebens SE (2015) Bevis i straffesaker: utvalgte emner. Gyldendal Juridisk, Oslo

Andersen P (2019) Processen i Danske Lov. In: Bang-Pedersen UR, Baumbach T, Scharf O and Stevnsborg H (eds) Retsplejeloven 100 år, DJøF Forlag, København

Arnesen J (1762) Historisk Indledning til den gamle og nye Islandske Rættergang. Trykt hos Joh. Boppenhausen, Kiøbenhavn

Backer IL (2018) Styrket nordisk lovsamarbeid: muligheter og utfordringer. Nordisk ministerråd, Denmark

Bellander H (2017) Rättegångskostnader: om kostnadsbördan i dispositiva tvistemål. Iustus förlag, Uppsala

Björne L (1998) Brytningstiden: Den nordiske rättsvetenskapens historia. Rättshistoriskt bibliotek vol. LVIII. Institutet för rättshistorisk forskning, Lund

Bylander E, Lindblom PH (2005) Muntlighet vid domstol i Norden. Iustus förlag, Uppsala Departements-Tidende (1830)

Ervo L (2009) Characteristics of procedure. In: Ervo L (ed) Civil justice in Finland, Nagoya University comparative study of civil justice, vol 2. Jigakusha Publishing, Tokyo, pp 55-100

\footnotetext{
${ }^{91}$ An example is the Nordic Procedural Law Conference, which is held every third year under the direction of the Nordic Association for Process Law.

${ }^{92}$ Some examples: From Denmark: U.2019.3878, which refers to Swedish and Norwegian law. From Norway: HR-2019-1954-A, where the Supreme Court refers to Swedish law, and Rt. 2008 p. 1730, where the Supreme Court refers to both Swedish and Danish law. From Sweden: NJA 2008 p. 733, which refers to Danish and Norwegian law. From Finland: KKO:2005:34, which refers to Swedish law. Icelandic case law has unfortunately not been available.

${ }^{93}$ Two of many possible examples: The Danish book Gomard and Kistrup (2007), where reference is made to Swedish law on page 226, and the Norwegian book Aarli, Hedlund and Jebens (2015), where reference is made to Danish law on pp. 421, 592 and 625.

${ }^{94}$ Korpiola (1999), Bylander and Lindblom (2005) and Heivoll and Flaaten (2017) could also be mentioned, among other publications.
} 
Gärde N (1931) Rättegångsreformen: några synpunkter. SvJT 1931:1-16

Gomard B, Kistrup M (2007) Civilprocessen. Thomson, København

Hagerup F (1899) Den nye østerrigske civilproces. Tidsskrift for Retsvidenskap 1899:241-314

Heivoll G, Flaatten S (2017) Rettslige overgangsformer: Politi- og kriminalrett i nordisk rettsutvikling. Akademisk publisering, Oslo

Hjort MA (2007) Muntlighetsprinsippet i sivilprosessen: Fra klubbeslag til tastetrykk. Institutt for offentlig retts skriftserie, Oslo

Hjort MA (2021) Development of the Nordic procedural law. Forthcoming article in Oslo Law Review

Justitsministeriet (1998) Justitsministeriets kommissorium av 19. januar 1998

Kekkonen J (2009) Roots of civil procedure in Finland from the point of view of modernity. In: Ervo L (ed) Civil justice in Finland, Nagoya university comparative study of civil justice. Jigakusha Publishing, Tokyo, pp 3-16

Knoph R (1998) Knophs oversikt over Norges rett, 11th Ed. by Kåre Lilleholt. Universitetsforlaget, Oslo

Korpiola P (1999) Nordic perspectives on medieval canon law. Matthias Calonius Society, Helsinki

Letto-Vanamo P (2012) Finnish law in European perspective. In: Nuotio K, Melander S, HuomoKettunen M (eds) Introduction to Finnish law and legal culture. Forum Iuris, Publications of the Faculty of Law University of Helsinki, Helsinki

Letto-Vanamo P, Tamm D (2019) Nordic legal mind. In: Letto-Vanamo P, Tamm D, Mortensen BOG (eds) Nordic law in European context. Springer, Cham, pp 1-19

Lindblom PH (2000) Civilprocessens grundprinciper de lege ferenda: synspunkter i ansluntning till det aktuella civilprocessuella reformarbetet i England, Danmark, Finland, Norge och Sverige. In: Lindblom PH, Progressiv process: spridda uppsatser om domstolsprocessen och samhällsutvecklingen. Iustus förlag, Uppsala

Mathiesen T (2011) Retten i samfunnet: en innføring i rettssosiologi. Pax forlag, Oslo

Mattei U (1994) Efficiency in legal transplants: an essay in comparative law and economics. Int Rev Law Econ 14:3-19

Mousourakis G (2013) Legal transplants and legal development: a jurisprudential and comparative law approach. Acta Juridica Hungaria 54:219-236

Nylund A, Sunde JØ (2019) Courts and court proceedings. In: Letto-Vanamo P, Tamm D, Mortensen BOG (eds) Nordic law in European context. Springer, Cham, pp 201-213

Robberstad K (1971) Rettssoga I. Universitetsforlaget, Oslo

Robberstad A (2004) Utenlandske sivilprosessforbilder: for Francis Hagerup og Tvistemålsutvalget (NOU 2001: 32). In: Andersson, Lindell (eds) Festskrift til Per Henrik Lindblom. Iustus förlag, Uppsala, pp 575-588

Schlyter K (1934) Högtidssammankomst å riddarhuset den 13 december 1934 ägnad 1734 års lag. Hälsningstal. SvJT 1934:529-531

Sigurðsson JV (2015) Kongemakt og lokalsamfunn på Island ca. 1260-1450. Heimen 52:17-24

Skyberg LF (2019) Prinsippet om fri bevisbedømmelse i et komparativt rettshistorisk og psykologisk perspektiv. TfS 2019:237-257

Uzelac A (2014) Goals of civil justice and civil procedure in the contemporary world. global developments: towards harmonisation (and back). In: Uzelac A (ed) Goals of civil justice and civil procedure in contemporary judicial systems. Springer, London, pp 3-31

Watson A (1974) Legal transplants, an approach to comparative law. Scottish Academic Press, Edinburgh

Watson A (2001) Society and legal change. Temple University Press, Philadelphia, USA 
Open Access This chapter is licensed under the terms of the Creative Commons Attribution 4.0 International License (http://creativecommons.org/licenses/by/4.0/), which permits use, sharing, adaptation, distribution and reproduction in any medium or format, as long as you give appropriate credit to the original author(s) and the source, provide a link to the Creative Commons license and indicate if changes were made.

The images or other third party material in this chapter are included in the chapter's Creative Commons license, unless indicated otherwise in a credit line to the material. If material is not included in the chapter's Creative Commons license and your intended use is not permitted by statutory regulation or exceeds the permitted use, you will need to obtain permission directly from the copyright holder.

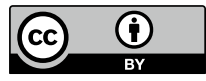

